\title{
К ВОПРОСУ О НЕКОТОРЫХ АКТУАЛЬНЫХ ПРОБЛЕМАХ, ВОЗНИКАЮЩИХ ПРИ ПЕРЕОФОРМЛЕНИИ ЛИЦЕНЗИИ
}

\begin{abstract}
Аннотация. Предметом исследования являются проблемы правового и организационного характера, связанные с административно-правовым регулированием деятельности лицензирующих органов. Статья посвящена вопросам, связанным с переоформлением лицензии. Автором проанализированы исчерпывающие перечни оснований переоформления лицензии, определенные в Федеральном законе от 4 мая 2011 г. № 99-Ф3 «О лицензировании отдельных видов деятельности». Несмотря на то, что указанный Федеральный закон принят достаточно давно, до сих пор возникают вопросы о необходимости переоформления лицензий, полученных до дня вступления в силу данного Федерального закона. Автором рассмотрены основные случаи переоформления лицензии, а также проблемы, которые возникают на практике в связи $c$ отсутствием в указанном Федеральном законе срока подачи заявления о переоформлении соответствующей лицензии. Методологическую основу статьи составили современные достижения теории познания. В процессе исследования применялись общенаучные и частнонаучные методы познания. Общенаучные методы (системный метод, анализ, синтез, аналогия, наблюдение, моделирование, сравнение), позволили выявить основные тенденции и закономерности развития изучаемого предмета. частнонаучные методы (формально-юридический, сравнительно-правовой, системно-структурный) дали возможность выделить, описать и воспроизвести исследуемые явления, сопоставить их с целью выявления сходства и различия. Новизна исследования заключается в том, что ранее проблемы, связанные с переоформлением лицензий, комплексно научным сообществом не рассматривались. Автор делает вывод о необходимости внесения соответствующих изменений в Федеральный закон от 4 мая 2011 г. № 99-Ф3 «О лицензировании отдельных видов деятельности» в части систематизации случаев переоформления лицензии и установления 8 статье 18 срока, в течение которого лицензиат обязан переоформить лицензию.
\end{abstract}

Ключевые слова: нормативно-правовое регулирование, государственная услуга, государственный контроль (надзор), положение о лицензировании, переоформление лицензии, лицензионные требования, лицензионный контроль, лицензирование, контрольно-надзорная функция, лицензирующий орган.

Abstract. The research subject is the range of legal and organizational problems of administrative regulation of the activities of licensing authorities. The paper considers the problems of re-licensing. The author analyzes the comprehensive lists of reasons for re-licensing provided by the Federal Law of 4 May 2011 No 99 "On the particular types of activity licensing". Despite the fact that this Federal Law was adopted quite a long time ago, the questions about the need for the renewal of licences, issued before this law enactment, are still urgent. The author considers the general cases of re-licensing and the practical problems caused by the absence of the deadline for submission of an application for re-licensing in the Federal Law. The research methodology is based on the recent achievements in epistemology. The author applies general scientific and specific methods. General scientific methods, including the system method, analysis, synthesis, analogy, observation, modeling and comparison, help reveal the main trends and patters of development of the research subject. Special scientific methods, including the formal-logical, comparative-legal and system-structural, provide the opportunity to detect, describe and reproduce the phenomena under consideration, and to compare them. The scientific novelty consists in the fact that so far, the problems of relicensing haven't been studied consistently. The author concludes about the necessity to amend the Federal Law of 4 May 2011 No 99 "On the particular types of activity licensing" in relation to systematization of cases of re-licensing and introduction of a deadline for relicensing in the article 18.

Key words: licensing authority, supervisory function, legal regulation, state service, state control (supervision), regulation on licensing, re-licensing, license requirements, license control, licensing.

$\mathrm{B}$ соответствии с пунктом 1 статьи 49 Гражданского кодекса Российской Федерации (далее ГК РФ) в случаях, предусмотренных законом, юридическое лицо может заниматься отдельными видами деятельности только на основании лицензии. Отношения, возникающие между федеральными органами исполнительной власти, органами исполнительной власти субъектов Российской Федерации, юридическими лицами и индивидуальными предпринимателями в связи с осуществлением лицензирования отдельных видов деятельности, регулируются Федеральным законом от 4 мая 2011 г. № 99-Ф3 «О лицензировании отдельных видов деятельности» (далее - Закон о лицензировании). 
Согласно Закону о лицензировании лицензирование отдельных видов деятельности осуществляется в целях предотвращения ущерба правам, законным интересам, жизни или здоровью граждан, окружающей среде, объектам культурного наследия (памятникам истории и культуры) народов Российской Федерации, обороне и безопасности государства, возможность нанесения которого связана с осуществлением юридическими лицами и индивидуальными предпринимателями отдельных видов деятельности. Осуществление лицензирования отдельных видов деятельности в иных целях не допускается. Задачами лицензирования отдельных видов деятельности являются предупреждение, выявление и пресечение нарушений юридическим лицом, его руководителем и иными должностными лицами, индивидуальным предпринимателем, его уполномоченными представителями требований, которые установлены указанным Федеральным законом, другими федеральными законами и принимаемыми в соответствии с ними иными нормативными правовыми актами Российской Федерации. Соответствие соискателя лицензии этим требованиям является необходимым условием для предоставления лицензии, их соблюдение лицензиатом обязательно при осуществлении лицензируемого вида деятельности.

Под лицензируемым видом деятельности в рамках Закона о лицензировании понимается вид деятельности, на осуществление которого на территории Российской Федерации и на иных территориях, над которыми Российская Федерация осуществляет юрисдикцию в соответствии с законодательством Российской Федерации и нормами международного права, требуется получение лицензии в соответствии с указанным Федеральным законом, в соответствии с иными федеральными законами, регулирующими отношения в соответствующих сферах деятельности.

Поскольку законодательство Российской Федерации в различных сферах деятельности постоянно изменяется, а, следовательно, и меняются нормативные правовые акты в сфере лицензирования, в статье предлагается рассмотреть некоторые актуальные проблемы, возникающие у лицензиатов и лицензирующих органов, при переоформлении лицензии.

Поскольку в Законе о лицензировании отсутствует определение понятия «переоформление лицензии», что приводит к определенным трудностям в правоприменительной практике, о которых будет написано ниже, представляется целесообразным рассмотреть, что включает в себя такая процедура как переоформление лицензии.

Для начала необходимо понять, что такое «лицензия». В пункте 2 статьи 3 Закона о лицензиро- вании дается определение понятия «лицензия» как специальное разрешение на право осуществления юридическим лицом или индивидуальным предпринимателем конкретного вида деятельности (выполнения работ, оказания услуг, составляющих лицензируемый вид деятельности), которое подтверждается документом, выданным лицензирующим органом.

Таким образом, переоформление лицензии можно рассматривать как процедуру внесения лицензирующим органом изменений в лицензию.

Лицензирующий орган переоформляет лицензию по основаниям и в порядке, установленным Законом о лицензировании. Часть 1 статьи 18, а также части 4 и 6.1 статьи 22 Закона о лицензировании устанавливают случаи, при которых лицензия подлежит переоформлению. Вместе с тем необходимо обратить внимание, что частью 2 статьи 18 Закона о лицензировании предусмотрены исключения из общего правила об обязательности срочного переоформления лицензии и разрешается лицензиату осуществлять лицензируемый вид деятельности до переоформления лицензии. Для того, чтобы разобраться во всем многообразии оснований переоформления лицензий и определить возможность осуществления лицензиатом лицензируемого вида деятельности до проведения процедуры переоформления лицензии представим их в виде таблицы.

Предлагается детально рассмотреть перечисленные случаи переоформления лицензии.

\section{1. Реорганизация юридического лица}

Для начала необходимо отметить, что в соответствии со статьей 57 ГК РФ реорганизация юридического лица (слияние, присоединение, разделение, выделение, преобразование) может быть осуществлена по решению его учредителей (участников) или органа юридического лица, уполномоченного на то учредительным документом. Допускается реорганизация юридического лица с одновременным сочетанием различных ее форм, предусмотренных абзацем первым настоящего пункта. Допускается реорганизация с участием двух и более юридических лиц, в том числе созданных в разных организационно-правовых формах, если указанным Кодексом или другим законом предусмотрена возможность преобразования юридического лица одной из таких организационно-правовых форм в юридическое лицо другой из таких организационно-правовых форм.

Так, в соответствии с частью 1 статьи 18 Закона о лицензировании лицензия подлежит переоформлению в случае реорганизации юридического лица в форме преобразования. 
Правовые основания переоформления лицензии

\begin{tabular}{|c|c|c|c|}
\hline $\begin{array}{c}\text { № } \\
\text { П/ா }\end{array}$ & $\begin{array}{c}\text { Случаи необходимости } \\
\text { переоформления лицензии }\end{array}$ & $\begin{array}{l}\text { Правовые } \\
\text { основания }\end{array}$ & $\begin{array}{c}\text { Особенности переоформления лицен- } \\
\text { зии (имеется/отсутствует возмож- } \\
\text { ность осуществления деятельности } \\
\text { до переоформления лицензии }\end{array}$ \\
\hline 1. & Изменение наименования юридического лица & $\begin{array}{l}\text { Часть } 1 \text { статьи } \\
18 \text { Закона о ли- } \\
\text { цензировании }\end{array}$ & Имеется \\
\hline 2. & $\begin{array}{l}\text { Изменение адреса места нахождения юридического } \\
\text { лица }\end{array}$ & $\begin{array}{l}\text { Часть } 1 \text { статьи } \\
18 \text { Закона о ли- } \\
\text { цензировании }\end{array}$ & Имеется \\
\hline 3. & $\begin{array}{l}\text { Изменение места жительства, имени, фамилии и (в } \\
\text { случае, если имеется) отчества индивидуального } \\
\text { предпринимателя, реквизитов документа, удосто- } \\
\text { веряющего его личность }\end{array}$ & $\begin{array}{l}\text { Часть } 1 \text { статьи } \\
18 \text { Закона о ли- } \\
\text { цензировании }\end{array}$ & Имеется \\
\hline 4. & $\begin{array}{l}\text { Реорганизация юридического лица в форме преоб- } \\
\text { разования }\end{array}$ & $\begin{array}{l}\text { Части } 1 \text { и } 5 \text { ста- } \\
\text { тьи } 18 \text { Закона } \\
\text { о лицензирова- } \\
\text { нии }\end{array}$ & $\begin{array}{l}\text { Имеется, но не позднее чем через пятнад- } \\
\text { цать рабочих дней со дня внесения соот- } \\
\text { ветствующих изменений в единый госу- } \\
\text { дарственный реестр юридических лиц }\end{array}$ \\
\hline 5. & $\begin{array}{l}\text { Реорганизация юридического лица в форме слия- } \\
\text { ния }\end{array}$ & $\begin{array}{l}\text { Часть } 6 \text { статьи } \\
18 \text { Закона о ли- } \\
\text { цензировании }\end{array}$ & $\begin{array}{l}\text { Имеется, но при условии наличия у каж- } \\
\text { дого участвующего в слиянии юриди- } \\
\text { ческого лица на дату государственной } \\
\text { регистрации правопреемника реоргани- } \\
\text { зованных юридических лиц лицензии на } \\
\text { один и тот же вид деятельности }\end{array}$ \\
\hline 6. & $\begin{array}{l}\text { Изменение адреса места осуществления юридиче- } \\
\text { ским лицом или индивидуальным предпринимате- } \\
\text { лем лицензируемого вида деятельности }\end{array}$ & $\begin{array}{l}\text { Часть } 1 \text { статьи } \\
18 \text { Закона о ли- } \\
\text { цензировании }\end{array}$ & Отсутствует \\
\hline 7. & $\begin{array}{l}\text { Осуществление деятельности на территории субъ- } \\
\text { екта Российской Федерации при наличии лицензии } \\
\text { на конкретный вид деятельности, полученной ли- } \\
\text { цензирующим органом другого субъекта Россий- } \\
\text { ской Федерации }\end{array}$ & $\begin{array}{l}\text { Часть } 5 \text { статьи } 9 \\
\text { Закона о лицен- } \\
\text { Зировании }\end{array}$ & Отсутствует \\
\hline 8. & $\begin{array}{l}\text { Изменение перечня выполняемых работ, оказывае- } \\
\text { мых услуг, составляющих лицензируемый вид дея- } \\
\text { тельности }\end{array}$ & $\begin{array}{l}\text { Часть } 1 \text { статьи } \\
18 \text { Закона о ли- } \\
\text { цензировании }\end{array}$ & Отсутствует \\
\hline 9. & $\begin{array}{l}\text { Изменение наименования видов деятельности, под- } \\
\text { лежащих лицензированию }\end{array}$ & $\begin{array}{l}\text { Часть } 6.1 \text { статьи } \\
22 \text { Закона о ли- } \\
\text { цензировании }\end{array}$ & Отсутствует \\
\hline 10. & $\begin{array}{l}\text { Если нормативными правовыми актами Российской } \\
\text { Федерации виды деятельности, ранее не содержа- } \\
\text { щие перечней работ, услуг, дополнены перечнями } \\
\text { работ, услуг, которые выполняются, оказываются в } \\
\text { составе конкретных видов деятельности }\end{array}$ & $\begin{array}{l}\text { Часть } 6.1 \text { статьи } \\
22 \text { Закона о ли- } \\
\text { цензировании }\end{array}$ & Отсутствует \\
\hline 11. & $\begin{array}{l}\text { Если нормативными правовыми актами Российской } \\
\text { Федерации в перечни работ, услуг, которые выпол- } \\
\text { няются, оказываются в составе конкретных видов } \\
\text { деятельности, внесены изменения }\end{array}$ & $\begin{array}{l}\text { Часть } 6.1 \text { статьи } \\
22 \text { Закона о ли- } \\
\text { цензировании }\end{array}$ & Отсутствует \\
\hline 12. & $\begin{array}{l}\text { Переоформление лицензии, полученной до дня } \\
\text { вступления в силу Закона о лицензировании }\end{array}$ & $\begin{array}{l}\text { Часть } 4 \text { статьи } \\
22 \text { Закона о ли- } \\
\text { цензировании }\end{array}$ & Отсутствует \\
\hline
\end{tabular}

Согласно пункту 1 статьи 68 ГК РФ хозяйственные товарищества и общества одного вида могут преобразовываться в хозяйственные товарищества и общества другого вида или в производственные кооперативы по решению общего собрания участников в порядке, установленном указанным Кодексом и законами о хозяйственных обществах.

При этом, в указанном случае по истечении пятнадцати рабочих дней со дня внесения соответствующих изменений в единый государствен- ный реестр юридических лиц, лицензиат не имеет права осуществлять лицензируемый вид деятельности до переоформления лицензии (части 2 и 5 статьи 18 Закона о лицензировании).

Это обусловлено тем, что предоставление лицензии является государственной услугой и в соответствии с Федеральным законом от 27 июля 2010 г. № 210-Ф3 «Об организации предоставления государственных и муниципальных услуг» оказывается исключительно по заявлению заинтересованного лица. 
Необходимо отметить, что согласно пункту 1 статьи 49 ГК РФ в случаях, предусмотренных законом, юридическое лицо может заниматься отдельными видами деятельности только на основании специального разрешения (лицензии).

Таким образом, при отсутствии заявления о переоформлении лицензии в случае реорганизации лица в форме преобразования осуществление лицензируемого вида деятельности по истечении пятнадцати рабочих дней со дня внесения соответствующих изменений в единый государственный реестр юридических лиц будет являться нарушением требований Закона о лицензировании.

Вместе с тем, при подаче в указанный пятнадцатидневный срок заявления о переоформлении лицензии в лицензирующий орган, представляется, что продолжение осуществления лицензиатом лицензируемого вида деятельности будет правомерно, поскольку согласно статье 18 Закона о лицензировании переоформление лицензии в данном случае осуществляется в срок не более десяти рабочих дней и включает в себя, по существу, проверку достоверности новых сведений, содержащихся в указанном заявлении и прилагаемых к нему документах.

Согласно части 6 статьи 18 Закона о лицензировании в случае реорганизации юридических лиц в форме слияния переоформление лицензии допускается только при условии наличия у каждого участвующего в слиянии юридического лица на дату государственной регистрации правопреемника реорганизованных юридических лиц лицензии на один и тот же вид деятельности.

Таким образом, в Законе о лицензировании предусмотрена обязанность лицензиата по переоформлению лицензии исключительно в случае его преобразования и слияния. Согласно пункту 3 части 13 статьи 20 Закона о лицензировании действие лицензии прекращается в связи с прекращением вида деятельности лицензиата, на который предоставлена лицензия в иных случаях реорганизации юридического лица (присоединение, разделение, выделение).

\section{2. Изменение наименования юридического лица, адреса его места нахождения, места жительства, имени, фамилии и (в случае, если имеется) отчества индивидуального предпринимателя, реквизитов документа, удостоверяющего его личность}

Так, в соответствии с частью 2 статьи 18 Закона о лицензировании в случае изменения наименования юридического лица, адреса его места нахождения, места жительства, имени, фамилии и (в случае, если имеется) отчества индивидуального предпринимателя, реквизитов документа, удостоверяющего его личность, лицензиат вправе осуществлять лицензируемый вид деятельности до переоформления лицензии.

Полагаем, что предлагаемая законодателем возможность осуществления лицензируемого вида деятельности до переоформления лицензии по указанным основаниям связана с тем, что, по существу, процедура переоформления лицензии в данном случае включает в себя проверку достоверности содержащихся в заявлении лицензиата новых сведений и внесения соответствующих изменений в лицензию, при этом не касаясь лицензируемого вида деятельности и не затрагивая права и законные интересы иных лиц.

Ситуация № 1 .

Вопрос о необходимости переоформления лицензии возникает у некоторых лицензиатов в связи с вступлением в силу Федерального закона от 5 мая 2014 г. № 99-ФЗ «О внесении изменений в главу 4 части первой Гражданского кодекса Российской Федерации и о признании утратившими силу отдельных положений законодательных актов Российской Федерации» (далее - Федеральный закон № 99-ФЗ).

В соответствии с частью 7 статьи 3 Федерального закона № 99-ФЗ учредительные документы, а также наименования юридических лиц, созданных до дня вступления в силу указанного закона, подлежат приведению в соответствие с нормами главы 4 Гражданского кодекса Российской Федерации при первом изменении учредительных документов таких юридических лиц.

Согласно пункту 1 статьи 54 Гражданского кодекса Российской Федерации одной из составляющих наименования юридического лица является указание на его организационно-правовую форму, в связи с чем изменение организационно-правовой формы является основанием для переоформления лицензии.

Однако согласно части 7 статьи 3 Федерального закона № 99-ФЗ изменение наименование юридического лица в связи с приведением его в соответствие с нормами главы 4 Гражданского кодекса Российской Федерации не требует внесения изменений в правоустанавливающие и иные документы, содержащие его прежнее наименование.

Следовательно, можно сделать вывод о том, что такое изменение не потребует переоформления лицензии в случае ее получения юридическим лицом, созданным до вступления в силу Федерального закона № 99-ФЗ.

При этом необходимо отметить, что до переоформления лицензии в случае изменения наи- 
менования юридического лица, лицензиат вправе осуществлять лицензируемый вид деятельности (часть 2 статьи 18 Закона о лицензировании).

Федеральным законом № 99-Ф3 также предусмотрено, что учредительные документы юридических лиц, созданных до вступления в силу указанного закона, до приведения их в соответствие с нормами главы 4 Гражданского кодекса Российской Федерации действуют в части, не противоречащей указанным нормам.

Таким образом полагаем, что переоформление лицензии, полученной юридическим лицом до вступления в силу Федерального закона № 99-ФЗ, потребуется в случае, когда юридическим лицом, созданным до вступления в силу Федерального закона № 99-Ф3, будет внесено первое изменение в учредительные документы указанного юридического лица, предусматривающее реорганизацию юридического лица в форме преобразования, или изменение его наименования.

Принимая во внимание бессрочное действие лицензии (часть 4 статьи 9 Закона о лицензировании), представляется, что эти изменения могут быть внесены по инициативе лицензиата при переоформлении лицензии по иным основаниям, предусмотренным Законом о лицензировании.

\section{3. Изменение адреса места осуществления лицензируемого вида деятельности}

Так, согласно части 1 статьи 18 Закона о лицензировании лицензия подлежит переоформлению в случае изменения адреса места осуществления лицензируемого вида деятельности.

В целях определения адреса места осуществления деятельности следует руководствоваться определением, установленным в пункте 8 статьи 3 Закона о лицензировании.

В частности, место осуществления лицензируемого вида деятельности - объект (помещение, здание, сооружение, иной объект), который предназначен для осуществления лицензируемого вида деятельности и (или) используется при его осуществлении, соответствует лицензионным требованиям, принадлежит соискателю лицензии или лицензиату на праве собственности либо ином законном основании, имеет почтовый адрес или другие позволяющие идентифицировать объект данные. Место осуществления лицензируемого вида деятельности может совпадать с местом нахождения соискателя лицензии или лицензиата.

Таким образом, в лицензии указывается либо адрес места осуществления лицензируемого вида деятельности, либо другие, позволяющие идентифицировать объект, данные, при условии, что к ним установлены лицензионные требования, и он принадлежит соискателю лицензии или лицензиату на любом законном основании.

В случае, если место осуществления лицензируемого вида деятельности не отвечает всем вышеназванным условиям в совокупности, в качестве места осуществления лицензируемого вида деятельности указывается место нахождения лицензиата.

Следует обратить внимание на то, что лицензия подлежит переоформлению как в случае добавления лицензиатом нового места осуществления лицензируемого вида деятельности, так и в случае, если осуществление лицензируемого вида деятельности прекращено по адресу, указанному в лицензии.

Ситуация № 2 .

Рассмотрим необходимость переоформления лицензии в связи с изменением адреса места осуществления лицензируемого вида деятельности при переименовании улиц, а также при изменении адресов зданий, строений, сооружений, объектов, произошедших, например, в связи с изменением границ между субъектами Российской Федерации городом Москвой и Московской областью с 1 июля 2012 г.

Как уже отмечалось выше, исчерпывающий перечень оснований для переоформления лицензии определен в статьях 18 и 22 Закона о лицензировании.

Данный перечень не содержит основания переоформления лицензии при изменении наименования улицы или номера дома, указываемых в адресе места осуществления лицензируемого вида деятельности.

Вместе с тем с 1 июля 2014 г. отношения, возникающие в связи с ведением государственного адресного реестра, осуществлением эксплуатации Федеральной информационной адресной системы - ФИАС, а также отношения по использованию содержащихся в государственном адресном реестре сведений об адресах, регулируются Федеральным законом от 28 декабря 2013 г. № 443-Ф3 «0 федеральной информационной адресной системе и о внесении изменений в Федеральный закон «Об общих принципах организации местного самоуправления в Российской Федерации» (далее - Федеральный закон № 443-ФЗ).

Согласно части 1 статьи 4 Федерального закона № 443-ФЗ в государственный адресный реестр вносятся сведения об адресах и о реквизитах документов о присвоении, об изменении, аннулировании адресов. В случае изменения или аннулирования адреса ранее внесенные в государственный адресный реестр сведения об адресе сохраняются 


\section{Административное и муниципальное право 8 (104) 2016}

в государственном адресном реестре со статусом «архивная информация».

Содержащиеся в государственном адресном реестре сведения об адресах являются общедоступной информацией, размещаемой, в том числе в форме открытых данных, а также обязательны для использования органами государственной власти, органами местного самоуправления, в том числе при предоставлении государственных услуг и муниципальных услуг, а также для использования при оказании услуг почтовой связи (статья 8 Федерального закона № 443-ФЗ).

Переименование улиц и изменение адресов зданий, строений, сооружений, объектов осуществляются государственными и муниципальными органами в соответствии с законодательством Российской Федерации, данные о таких изменениях носят официальный характер и подлежат обязательному размещению в ФИАС, которая содержит данные о старых и новых наименованиях улиц, а также об изменениях адресов зданий, строений, сооружений, объектов, доступ к такой информации является открытым, в том числе для лицензирующих органов.

Кроме того данные изменения не влекут за собой юридические последствия, поскольку не оказывают влияние на безопасность осуществления лицензируемого вида деятельности.

Таким образом, в Законе о лицензировании обязанность лицензиата по переоформлению лицензии в указанных случаях не предусмотрена, поскольку переименования улиц и изменения адресов зданий, строений, сооружений, объектов не осуществляются по инициативе лицензиатов, не являются персональными данными, носят официальный и общедоступный характер.

Принимая во внимание бессрочное действие лицензии, полагаем, что такие изменения могут быть внесены по инициативе лицензиата при переоформлении лицензии по иным основаниям, предусмотренным Законом о лицензировании.

\section{4. Осуществление деятельности на территории субъекта Российской Федерации при наличии лицензии на конкретный вид деятельности, полученной лицензирующим органом другого субъекта Российской Федерации}

Рассматриваемая ниже ситуация, по существу, является одной из разновидности ситуации, изложенной в предыдущем разделе статьи.

Так, в силу статьи 9 Закона о лицензировании лицензия предоставляется на каждый вид деятельности, указанный в части 1 статьи 12 указанного Федерального закона. Юридическое лицо или индивидуальный предприниматель, получившие лицензию, вправе осуществлять деятельность, на которую предоставлена лицензия, на всей территории Российской Федерации и на иных территориях, над которыми Российская Федерация осуществляет юрисдикцию в соответствии с законодательством Российской Федерации и нормами международного права, со дня, следующего за днем принятия решения о предоставлении лицензии.

При этом согласно части 5 статьи 9 Закона о лицензировании деятельность, на осуществление которой лицензия предоставлена лицензирующим органом субъекта Российской Федерации, может осуществляться на территориях других субъектов Российской Федерации при условии уведомления лицензиатом лицензирующих органов соответствующих субъектов Российской Федерации в порядке, установленном Правительством Российской Федерации. Порядок уведомления установлен в постановлении Правительства Российской Федерации от 21 ноября 2011 г. № 957 «Об организации лицензирования отдельных видов деятельности». Согласно пункту 3 указанного постановления Правительства Российской Федерации лицензирующий орган субъекта Российской Федерации переоформляет лицензию в порядке, установленном Законом о лицензировании, и вносит изменения в реестр лицензий в отношении видов деятельности, лицензирование которых он осуществляет.

Порядок переоформления лицензии определен в статье 18 Закона о лицензировании, согласно которому лицензия подлежит переоформлению, в том числе в случае изменения адресов мест осуществления юридическим лицом лицензируемого вида деятельности. При намерении лицензиата осуществлять лицензируемый вид деятельности по адресу места его осуществления, не указанному в лицензии, в заявлении о переоформлении лицензии указываются новый адрес и сведения, подтверждающие соответствие лицензиата лицензионным требованиям при осуществлении лицензируемого вида деятельности по этому адресу.

В силу части 3 статьи 18 Закона о лицензировании для переоформления лицензии лицензиат, его правопреемник или иное предусмотренное федеральным законом лицо представляет в лицензирующий орган, предоставивший лицензию, либо направляет заказным почтовым отправлением с уведомлением о вручении заявление о переоформлении лицензии с указанием реквизитов документа, подтверждающего уплату государственной пошлины за переоформление лицензии, и оригинал действующей лицензии на бумажном носителе 
или лицензию в форме электронного документа, подписанного электронной подписью.

В связи с этим, можно сделать вывод о том, что переоформление лицензии осуществляет тот лицензирующий орган, который первоначально выдал соответствующую лицензию. Однако указанная норма противоречит принципу уведомления, предусмотренному в части 5 статьи 9 Закона о лицензировании, согласно которому лицензиат уведомляет лицензирующий орган соответствующего субъекта Российской Федерации, на территории которого планируется осуществление лицензируемого вида деятельности, что приводит к проблемам в правоприменительной практике.

\section{5. Изменение нормативными правовыми актами Российской Федерации перечня выполняемых работ, оказываемых услуг, составляющих лицензируемый вид деятельности}

В соответствии с частью 1 статьи 18 Закона о лицензировании лицензия подлежит переоформлению в случае изменения перечня выполняемых работ, оказываемых услуг, составляющих лицензируемый вид деятельности.

Исходя из смысла нормы части 2 статьи 18 Закона о лицензировании, до переоформления лицензии лицензиат не имеет права выполнять работы, оказывать услуги, составляющие лицензируемый вид деятельности, но не указанные в лицензии.

Таким образом, в случае изменения перечня выполняемых работ, оказываемых услуг, составляющих лицензируемый вид деятельности, лицензиату необходимо переоформить лицензию.

В случае если перечни лицензионных требований после изменения перечня выполняемых работ, оказываемых услуг, составляющих лицензируемый вид деятельности, не изменились, переоформление лицензии будет заключаться во внесении в лицензию перечня работ, оказываемых услуг в составе данного вида деятельности.

Статья 18 Федерального закона № 99-Ф3 предусматривает порядок переоформления лицензии. При этом следует отметить, что срок предоставления лицензиатом в лицензирующий орган заявления о переоформлении лицензии, не предусмотрен.

В совокупности, учитывая положения части 2 статьи 18 Закона о лицензировании, а также пункта 1 статьи 49 ГК РФ, по нашему мнению, лицензиату необходимо пройти процедуру переоформления лицензии в возможно короткий срок с момента внесения изменений в перечень выполняемых ра- бот, оказываемых услуг в составе лицензируемого вида деятельности.

\section{6. Переоформление лицензии, в связи с изменением наименования видов деятельности, подлежащих лицензированию}

Частью 6.1 статьи 22 Закона о лицензировании (введенной Федеральным законом от 14 октября 2014 г. № 307-Ф3 «0 внесении изменений в Кодекс Российской Федерации об административных правонарушениях и отдельные законодательные акты Российской Федерации и о признании утратившими силу отдельных положений законодательных актов Российской Федерации в связи с уточнением полномочий государственных органов и муниципальных органов в части осуществления государственного контроля (надзора) и муниципального контроля») предусмотрено, что лицензии на виды деятельности, наименования которых изменены, подлежат переоформлению в порядке, установленном настоящей статьей, при условии соблюдения лицензионных требований, предъявляемых к таким видам деятельности (выполнению работ, оказанию услуг, составляющих лицензируемый вид деятельности).

Вместе с тем в данной статье отсутствует порядок переоформления лицензий. Порядок переоформления лицензии определен в статье 18 Закона о лицензировании.

Необходимо отметить, что официальным отзывом Правительства Российской Федерации от 2 марта 2015 г. № 1197п-П16 на проект федерального закона № 630498-6 «0 внесении изменений в Федеральный закон «0 лицензировании отдельных видов деятельности», принятого Государственной Думой Федерального Собрания Российской Федерации в I чтении 17 марта 2015 г., предлагается в части 6.1 указанной статьи слова «подлежат переоформлению в порядке, установленном настоящей статьей» заменить словами «подлежат переоформлению в порядке, установленном статьей 18 настоящего Федерального закона».

В связи с этим полагаем, что до внесения соответствующих изменений в статью 22 Федерального закона № 99-ФЗ при переоформлении лицензии в случаях, предусмотренных частью 6.1 статьи 22 Федерального закона № 99-Ф3, целесообразно применять порядок, предусмотренный статьей 18 указанного Федерального закона.

При этом обращаем внимание, что в данном случае, так же как и в предыдущем, в статье 18 Закона о лицензировании отсутствует срок направления заявления о переоформлении лицензии, что влечет неоднозначность толкования соответствующей правовой нормы. 


\section{7. Переоформление лицензии, полученной до дня вступления в силу Закона о лицензировании}

В соответствии с частью 4 статьи 22 Закона о лицензировании предоставленные до дня вступления в силу Закона о лицензировании лицензии на виды деятельности, наименования которых изменены, а также лицензии, не содержащие перечня работ, услуг, которые выполняются, оказываются в составе конкретных видов деятельности, по истечении срока их действия подлежат переоформлению, при условии соблюдения лицензионных требований, предъявляемых к таким видам деятельности (выполнению работ, оказанию услуг, составляющих лицензируемый вид деятельности).

Кнутов А.В. и Чаплинский А.В. в своей работе считают положительным тот момент, что с принятием в 2011 и 2012 гг. поправок в часть 3 статьи 22 Закона о лицензировании норма о том, что лицензии, которые были предоставлены и срок действия которых не истек до дня вступления в силу Закона о лицензировании, действуют бессрочно. Таким образом снижены затраты бизнеса на кампанию по переоформлению лицензий [14].

Вместе с тем обращаем внимание, что в части 1 статьи 18 и части 4 статьи 22 Закона о лицензировании установлены случаи, при которых требуется переоформление лицензии. А в 2014 году в статью 22 Закона о лицензировании введена новая часть 6.1 , которая добавляет перечень оснований для переоформления лицензии.

При детальном рассмотрении указанных положений становится ясно, что переоформление лицензий, полученных до дня вступления в силу Закона о лицензировании, необходимо осуществить каждому лицензиату. Так, согласно части 2 статьи 17 Федерального закона от 8 августа 2001 г. № 128-Ф3 «0 лицензировании отдельных видов деятельности» (действовавшему до вступления в силу Закона о лицензировании) положениями о лицензировании конкретных видов деятельности устанавливается перечень работ и услуг по девяти видам деятельности. При этом, исходя из части 1 указанной статьи, до 2011 года лицензирование осуществлялось по 105 видам деятельности.

Таким образом, можно сделать вывод о том, что предыдущим Федеральным законом практически не предусматривалось разделение лицензируемых видов деятельности на виды выполняемых работ, оказываемых услуг. Частью 2 статьи 12 Закона о лицензировании предусмотрено, что положениями о лицензировании конкретных видов деятельности устанавливаются исчерпывающие перечни выполняемых работ, оказываемых услуг, составляющих лицензируемый вид деятельности, в случае, если указанные перечни не установлены федеральными законами.

То есть, проведя анализ положений о лицензировании конкретных видов деятельности, можно сделать вывод о том, что практически все лицензируемые виды деятельности содержат набор перечней выполняемых работ, оказываемых услуг, составляющих лицензируемый вид деятельности. Исходя из смысла нормы части 2 статьи 18 Закона о лицензировании, до переоформления лицензии лицензиат не имеет права выполнять работы, оказывать услуги, составляющие лицензируемый вид деятельности, но не указанные в лицензии.

Статья 18 Закона о лицензировании предусматривает порядок переоформления лицензии. При этом срок предоставления лицензиатом в лицензирующий орган заявления о переоформлении лицензии не предусмотрен. Обращаем внимание, что согласно пункту 1 статьи 49 ГК РФ в случаях, предусмотренных законом, юридическое лицо может заниматься отдельными видами деятельности только на основании специального разрешения (лицензии).

С учетом изложенного, с целью продолжения осуществления деятельности лицензиат обязан переоформить лицензию, полученную до вступления в силу Закона о лицензировании, в части, например, указания вида работ, услуг, которые выполняются, оказываются в составе соответствующего вида деятельности, в срок, позволяющем непрерывно осуществлять такую деятельность на законном основании.

В случае если перечни лицензионных требований, указанные в Положении о лицензировании конкретного вида деятельности, принятого во исполнение Закона о лицензировании, по сравнению с перечнями, определенными в ранее действующем Положении о лицензировании конкретного вида деятельности, не изменились, переоформление лицензии будет заключаться во внесении в лицензию перечня работ, оказываемых услуг в составе данного вида деятельности.

При этом следует учитывать заключительные положения Закона о лицензировании, которые, на наш взгляд, могут ответить на вопрос о действительной воле законодателя. Вопрос заключается в том, были ли направлены положения Закона о лицензировании на создание условий для практически сплошного проведения проверок лицензиатов при переоформлении ранее выданных лицензий или предполагалась минимизация административных барьеров, порождаемых вступлением в силу нового закона? Часть 4 статьи 22 Закона о лицензировании устанавливает закрытый перечень оснований для переоформления лицензий (по ис- 
течении срока их действия) в связи с вступлением закона в силу:

- изменение наименования лицензируемого вида деятельности;

- лицензии, не содержащие перечня работ, услуг, которые выполняются, оказываются в составе конкретных видов деятельности.

Обращаясь к регулированию вопросов переоформления ранее выданных лицензий в связи с вступлением в силу Закона о лицензировании, законодатель не указал в заключительных положениях закона на обязательность переоформление лицензий.

Вместе с тем, по нашему мнению, большинство лицензий, выданных до вступления в силу Закона о лицензировании, подлежат переоформлению, поскольку ни в одной из них не указаны адреса осуществления лицензируемого вида деятельности, поскольку ранее действовавшее законодательство не предусматривало таких требований.

Выявленная проблема чревата созданием серьезных административных барьеров в предпринимательской деятельности. Анализ судебной практики свидетельствует о том, что значительная часть споров возникает именно из отношений, связанных с переоформлением лицензии и проведением в связи с этим проверок. Полагаем, что потребуется внесение изменений в переходные положения Закона о лицензировании, чтобы более четко отразить волю законодателя по данному вопросу.

\section{Выводы и предложения по внесению изменений в Закон о лицензировании}

Анализируя вышеизложенное, можно сделать вывод о том, что Законом о лицензировании предусмотрены различные основания и порядок переоформления лицензии. При этом правовые основания переоформления лицензии можно условно разделить на три вида.

К первому виду можно отнести изменения, произошедшие по «вине» лицензиата, например, изменения его наименования, адреса места нахождения. Такие изменения не потребуют от лицензиата срочного переоформления лицензии, поскольку не оказывают влияние на лицензируемый вид деятельности, носят, по существу, документационный характер и могут быть оформлены в течение неопределенного периода времени.

Законодатель обоснованно разграничивают само право и документ, который его подтверждает. В случае переоформления лицензии само право сохраняется, изменяется лишь содержание и реквизиты правоудостоверяющего документа.

Судебная практика также выделяет право лицензиата на осуществление конкретного вида де- ятельности, отграничивая его от правоудостоверяющего документа (лицензии на материальном носителе или в электронной форме). Первичным является само специальное разрешение на право осуществления юридическим лицом или индивидуальным предпринимателем конкретного вида деятельности (выполнения работ, оказания услуг, составляющих лицензируемый вид деятельности). Документ, выданный лицензирующим органом на бумажном носителе или в форме электронного документа, подписанного электронной подписью (лицензия как правоудостоверяющий документ), является вторичным.

Полагаем, что несоблюдение требований к переоформлению лицензии, совершение иных формальных действий, может повлечь ответственность за нарушение лицензионных требований, предъявляемых к таким видам деятельности (выполнению работ, оказанию услуг, составляющих лицензируемый вид деятельности), но не меняет статус лица как лицензиата, не отменяет связанных с ним прав и обязанностей. Внесение (невнесение) изменений в документ, в связи с его переоформлением, не влияет на возможность реализации статуса, основанного на праве осуществлять лицензируемый вид деятельности.

Вместе с тем полагаем, что при подготовке изменений в Закон о лицензировании или подготовке нового Федерального закона о лицензировании отдельных видов деятельности следует более четко разграничить лицензию как право на осуществление деятельности и лицензию как правоудостоверяющий документ.

К первому виду правовых оснований переоформления лицензии относятся пункты 1-3 Таблицы.

Ко второму виду можно отнести изменения, произошедшие по «вине» лицензиата, но требующие срочного внесения изменений в лицензию, т.е. ее переоформление (пункты 4-8 Таблицы).

К третьему виду можно отнести изменения, произошедшие по «вине» законодателя, например, введение в лицензируемый вид деятельности ранее отсутствующего перечня работ, услуг, которые выполняются, оказываются в составе данного вида деятельности (пункты 9-12 Таблицы).

Изменения второго и третьего вида, с учетом положения ГК РФ, согласно которому юридическое лицо может заниматься отдельными видами деятельности только на основании специального разрешения (лицензии), в целях обеспечения непрерывного осуществления лицензиатом лицензируемого вида деятельности потребуют срочного переоформления лицензии.

Так, в соответствии с частью 2 статьи 18 Закона о лицензировании до переоформления лицен- 
зии лицензиат не вправе осуществлять лицензируемый вид деятельности по адресу, не указанному в лицензии, или по истечении пятнадцатидневного срока на подачу заявления о переоформлении в случае реорганизации юридического лица в форме преобразования, и (или) выполнения работ, оказания услуг, составляющих лицензируемый вид деятельности, но не указанных в лицензии.

Необходимо отметить, что ответственность за осуществление лицензируемого вида деятельности без лицензии установлена Кодексом Российской Федерации об административных правонарушениях и Уголовным кодексом Российской Федерации.

Так, согласно части 2 статьи 14.1 Кодекса Российской Федерации об административных правонарушениях осуществление предпринимательской деятельности без лицензии, если такая лицензия обязательна, влечет наложение административного штрафа на граждан в размере от двух тысяч до двух тысяч пятисот рублей с конфискацией изготовленной продукции, орудий производства и сырья или без таковой; на должностных лиц - от четырех тысяч до пяти тысяч рублей с конфискацией изготовленной продукции, орудий производства и сырья или без таковой; на юридических лиц - от сорока тысяч до пятидесяти тысяч рублей с конфискацией изготовленной продукции, орудий производства и сырья или без таковой.

Уголовная ответственность в соответствии со статьей 171 Уголовного кодекса Российской Федерации наступает в виде штрафа в размере до трехсот тысяч рублей или в размере заработной платы или иного дохода осужденного за период до двух лет, либо обязательными работами на срок до четырехсот восьмидесяти часов, либо арестом на срок до шести месяцев, в случае осуществления предпринимательской деятельности без лицензии, если такая лицензия обязательна и такое деяние причинило крупный ущерб гражданам, организациям или государству либо сопряжено с извлечением дохода в крупном размере. Крупным размером, крупным ущербом, доходом либо задолженностью в крупном размере признаются стоимость, ущерб, доход либо задолженность в сумме, превышающей один миллион пятьсот тысяч рублей, особо крупным - шесть миллионов рублей.

Таким образом, лицензиат должен быть заинтересован в организации процедуры переоформления лицензии в случае наступления соответствующих обстоятельств.

В связи с этим в Законе о лицензировании представляется целесообразным структурировать перечни оснований переоформления лицензий, изложенных в части 1 статьи 18, а также в части 6.1 статьи 22 Закона о лицензировании. Кроме того предлагается более четко изложить возможность осуществления лицензиатом лицензируемого вида деятельности до переоформления лицензии.

Так, части 1 и 2 статьи 18 Закона о лицензировании предлагается изложить в следующей редакции, исключив при этом часть 6.1 статьи 22 Закона о лицензировании:

«1. Лицензия подлежит переоформлению в случае:

1) изменения наименования юридического лица;

2) изменения адреса места нахождения юридического лица;

3) изменения места жительства индивидуального предпринимателя;

4) изменения имени, фамилии и (в случае, если имеется) отчества индивидуального предпринимателя;

5) изменения реквизитов документа индивидуального предпринимателя, удостоверяющего его личность;

6) реорганизации юридического лица в форме преобразования или слияния;

7) изменения адресов мест осуществления юридическим лицом или индивидуальным предпринимателем лицензируемого вида деятельности;

8) изменения лицензиатом перечня выполняемых работ, оказываемых услуг, составляющих лицензируемый вид деятельности;

9) изменения нормативными правовыми актами Российской Федерации наименования видов деятельности, подлежащих лицензированию;

10) установления нормативными правовыми актами Российской Федерации ранее не предусмотренного перечня выполняемых работ, оказываемых услуг, составляющих лицензируемый вид деятельности;

11) внесения нормативными правовыми актами Российской Федерации изменений в перечни работ, услуг, которые выполняются, оказываются в составе конкретных видов деятельности.

2. Лицензиат вправе осуществлять лицензируемый вид деятельности в случаях, предусмотренных пунктами 1-5 части 1 настоящей статьи, а также в случаях, указанных в пунктах 9-11 части 1 настоящей статьи, при условии, что лицензионные требования, предъявляемые к таким видам деятельности (выполнению работ, оказанию услуг, составляющих лицензируемый вид деятельности) не изменились. В указанных случаях внесение изменений в лицензию осуществляется лицензиатом при переоформлении лицензии по иным основаниям, предусмотренным Законом о лицензировании.». 
Следует отметить, что в Законе о лицензировании отсутствует срок, в течение которого лицензиатом должны быть поданы документы на переоформление лицензии. Данная проблема отражена в докладах о лицензировании за 2014 г. Федеральной службы по надзору в сфере транспорта и Федеральной службы государственной регистрации, кадастра и картографии, а также в ежегодном сводном докладе Минэкономразвития России «0 лицензировании отдельных видов деятельности в Российской Федерации за 2014 год», направленном в Правительство Российской Федерации. Выявленная проблема связана с тем, что в статьях 18 и 22 Закона о лицензировании предусмотрены случаи необходимости переоформления лицензии. При этом срок предоставления лицензиатом в лицензирующий орган сведений об изменении, например, наименования, места нахождения юридического лица или индивидуального предпринимателя, перечня выполняемых работ, составляющих лицензируемый вид деятельности, не предусмотрен.

В этой связи в статье 18 Закона о лицензировании целесообразно установить срок, в течение которого лицензиатом должны быть поданы документы на переоформление лицензии.

Полагаем, что данный срок должен составлять не более девяноста дней с момента наступления обстоятельств, являющихся основанием для переоформления лицензии в соответствии с Законом о лицензировании. Аналогичная норма содержится, например, в части 2 статьи 4 Федерального закона от 21 июля 2014 г. № 222-Ф3 «О внесении изменений в Федеральный закон «0 государственном регулировании деятельности по организации и проведению азартных игр и о внесении изменений в некоторые законодательные акты Российской Федерации» и отдельные законодательные акты Российской Федерации».

Так, с учетом вышеизложенных предложений, предлагается статью 18 Закона о лицензировании дополнить новой частью 2.1 следующего содержания:

«2.1. Лицензиат обязан обратиться в лицензирующий орган с заявлением о переоформлении лицензии не позднее девяноста дней с момента наступления обстоятельств, указанных в пункте 1 настоящей статьи, с учетом особенностей, предусмотренных частью 2 настоящей статьи.».

Как было написано в начале статьи, в Законе о лицензировании отсутствует понятие «переоформление лицензии». При этом согласно части 3 статьи 18 Закона о лицензировании для переоформления лицензии лицензиат, его правопреемник или иное предусмотренное федеральным законом лицо представляет в лицензирующий орган, предоставивший лицензию, либо направляет за- казным почтовым отправлением с уведомлением о вручении заявление о переоформлении лицензии с указанием реквизитов документа, подтверждающего уплату государственной пошлины за переоформление лицензии, и оригинал действующей лицензии на бумажном носителе или лицензию в форме электронного документа, подписанного электронной подписью. Главным в данной норме является то, что заявление подается в лицензирующий орган, предоставивший лицензию. Вместе с тем на практике в некоторых случаях реализовать в полном объеме данное требование невозможно.

Так, например, в случае наличия лицензии, полученной лицензирующим органом субъекта Российской Федерации и желанием лицензиата осуществлять лицензируемый вид деятельности на территории иного субъекта Российской Федерации, подать заявление о переоформлении лицензии (уведомление) необходимо в лицензирующий орган субъекта Российской Федерации, на территории которого планируется соответствующая деятельность. Аналогичная проблемная ситуация может возникнуть и в случае переоформлении лицензии в случае реорганизации юридического лица и нахождении соответствующих юридических лиц на территориях разных субъектов Российской Федерации.

В связи с этим в части 3 статьи 18 Закона о лицензировании полагаем необходимым исключить слова «предоставивший лицензию,».

И последняя проблема, связанная с переоформлением лицензии, которая в настоящее время прямо не урегулирована Законом о лицензировании, но в ближайшее время может возникнуть на практике. Это обязанность лицензиата по переоформлению лицензии в связи с изменением нормативными правовыми актами Российской Федерации лицензионных требований, предъявляемых к конкретным видам деятельности (выполнению работ, оказанию услуг, составляющих лицензируемый вид деятельности).

Так, например, Министерством культуры Российской Федерации разработан проект постановления Правительства Российской Федерации «О внесении изменений в Положение о лицензировании деятельности по сохранению объектов культурного наследия (памятников истории и культуры) народов Российской Федерации, утвержденное постановлением Правительства Российской Федерации от 19 апреля 2012 г. № 349» (далее соответственно - проект постановления, Положение). Проектом постановления предлагается внести изменения в Положение в части конкретизации перечня необходимого профессионального образования у работников соискателей лицензии (лицензиатов) [16]. 
Поскольку соответствие соискателя лицензии лицензионным требованиям, предъявляемым к конкретным видам деятельности (выполнению работ, оказанию услуг, составляющих лицензируемый вид деятельности), является необходимым условием для предоставления лицензии, их соблюдение лицензиатом обязательно также при осуществлении лицензируемого вида деятельности и после получения лицензии.

В связи с этим, несмотря на отсутствие в Законе о лицензировании прямой нормы о необходимости переоформления лицензии в случае изменения лицензионных требований, предъявляемых к конкретным видам деятельности (вы- полнению работ, оказанию услуг, составляющих лицензируемый вид деятельности), полагаем, что после принятия указанного проекта постановления или иных аналогичных нормативных правовых актов Правительства Российской Федерации лицензиаты будут обязаны переоформить имеющуюся у них лицензию в целях подтверждения соответствия новым лицензионным требованиям.

По нашему мнению, вышеуказанные предложения, в случае их внедрения в Законе о лицензировании, позволят улучшить правовое регулирование отношений, возникающих при переоформлении лицензии.

\section{Библиография:}

1. Гражданский кодекс Российской Федерации.

2. Кодекс Российской Федерации об административных правонарушениях.

3. Уголовный кодекс Российской Федерации.

4. Федеральный закон от 4 мая 2011 г. № 99-Ф3 «0 лицензировании отдельных видов деятельности».

5. Федеральный закон от 27 июля 2010 г. № 210-Ф3 «Об организации предоставления государственных и муниципальных услуг».

6. Федеральный закон от 14 октября 2014 г. № 307-Ф3 «0 внесении изменений в Кодекс Российской Федерации об административных правонарушениях и отдельные законодательные акты Российской Федерации и о признании утратившими силу отдельных положений законодательных актов Российской Федерации в связи с уточнением полномочий государственных органов и муниципальных органов в части осуществления государственного контроля (надзора) и муниципального контроля».

7. Федеральный закон от 5 мая 2014 г. № 99-Ф3 «0 внесении изменений в главу 4 части первой Гражданского кодекса Российской Федерации и о признании утратившими силу отдельных положений законодательных актов Российской Федерации».

8. Федеральный закон от 28 декабря 2013 г. № 443-Ф3 «О федеральной информационной адресной системе и о внесении изменений в Федеральный закон «Об общих принципах организации местного самоуправления в Российской Федерации».

9. Федеральный закон от 8 августа 2001 г. № 129-Ф3 «0 государственной регистрации юридических лиц и индивидуальных предпринимателей».

10. Федеральный закон от 21 июля 2014 г. № 222-Ф3 «0 внесении изменений в Федеральный закон «0 государственном регулировании деятельности по организации и проведению азартных игр и о внесении изменений в некоторые законодательные акты Российской Федерации» и отдельные законодательные акты Российской Федерации».

11. Федеральный закон от 8 августа 2001 г. № 128-Ф3 «О лицензировании отдельных видов деятельности».

12. Проект федерального закона № 630498-6 «0 внесении изменений в Федеральный закон «О лицензировании отдельных видов деятельности».

13. Постановление Правительства Российской Федерации от 21 ноября 2011 г. № 957 «Об организации лицензирования отдельных видов деятельности».

14. Кнутов А.В., Чаплинский А.В. Лицензирование отдельных видов экономической деятельности: история развития и современное состояние // Вопросы государственного и муниципального управления. 2014. № 1. С. 22.

15. Крупнова И.В., Старостина И.С. Актуальные вопросы лицензирования фармацевтической деятельности в свете нового федерального закона о лицензировании // Вестник Росздравнадзора. 2012. № 1. С. 43.

16. https://regulation.gov.ru/projects\#npa=20464.

\section{References (transliterated):}

1. Grazhdanskii kodeks Rossiiskoi Federatsii.

2. Kodeks Rossiiskoi Federatsii ob administrativnykh pravonarusheniyakh.

3. Ugolovnyi kodeks Rossiiskoi Federatsii.

4. Federal'nyi zakon ot 4 maya 2011 g. № $99-\mathrm{FZ}$ «0 litsenzirovanii otdel'nykh vidov deyatel'nosti».

5. Federal'nyi zakon ot 27 iyulya 2010 g. № 210-FZ «Ob organizatsii predostavleniya gosudarstvennykh i munitsipal'nykh uslug».

6. Federal'nyi zakon ot 14 oktyabrya 2014 g. № 307-FZ «O vnesenii izmenenii v Kodeks Rossiiskoi Federatsii ob administrativnykh pravonarusheniyakh i otdel'nye zakonodatel'nye akty Rossiiskoi Federatsii i o priznanii utrativshimi silu otdel'nykh polozhenii zakonodatel'nykh aktov Rossiiskoi Federatsii v svyazi s utochneniem polnomochii 
gosudarstvennykh organov i munitsipal'nykh organov v chasti osushchestvleniya gosudarstvennogo kontrolya (nadzora) i munitsipal'nogo kontrolya».

7. Federal'nyi zakon ot 5 maya 2014 g. № 99-FZ «0 vnesenii izmenenii v glavu 4 chasti pervoi Grazhdanskogo kodeksa Rossiiskoi Federatsii i o priznanii utrativshimi silu otdel'nykh polozhenii zakonodatel'nykh aktov Rossiiskoi Federatsii».

8. Federal'nyi zakon ot 28 dekabrya 2013 g. № $443-\mathrm{FZ}$ «O federal'noi informatsionnoi adresnoi sisteme i o vnesenii izmenenii v Federal'nyi zakon «Ob obshchikh printsipakh organizatsii mestnogo samoupravleniya v Rossiiskoi Federatsii».

9. Federal'nyi zakon ot 8 avgusta 2001 g. № $129-\mathrm{FZ}$ «O gosudarstvennoi registratsii yuridicheskikh lits i individual'nykh predprinimatelei».

10. Federal'nyi zakon ot 21 iyulya 2014 g. № 222-FZ «0 vnesenii izmenenii v Federal'nyi zakon «0 gosudarstvennom regulirovanii deyatel'nosti po organizatsii i provedeniyu azartnykh igr i o vnesenii izmenenii v nekotorye zakonodatel'nye akty Rossiiskoi Federatsii» i otdel'nye zakonodatel'nye akty Rossiiskoi Federatsii».

11. Federal'nyi zakon ot 8 avgusta 2001 g. № $128-\mathrm{FZ}$ «O litsenzirovanii otdel'nykh vidov deyatel'nosti».

12. Proekt federal'nogo zakona № $630498-6$ «0 vnesenii izmenenii v Federal'nyi zakon «0 litsenzirovanii otdel'nykh vidov deyatel'nosti».

13. Postanovlenie Pravitel'stva Rossiiskoi Federatsii ot 21 noyabrya 2011 g. № 957 «Ob organizatsii litsenzirovaniya otdel'nykh vidov deyatel'nosti».

14. Knutov A.V., Chaplinskii A.V. Litsenzirovanie otdel'nykh vidov ekonomicheskoi deyatel'nosti: istoriya razvitiya i sovremennoe sostoyanie // Voprosy gosudarstvennogo i munitsipal'nogo upravleniya. 2014. № 1. C. 22.

15. Krupnova I.V., Starostina I.S. Aktual'nye voprosy litsenzirovaniya farmatsevticheskoi deyatel'nosti v svete novogo federal'nogo zakona o litsenzirovanii // Vestnik Roszdravnadzora. 2012. № 1. S. 43.

16. https://regulation.gov.ru/projects\#npa=20464. 